clubs as opposed to playing golf properly. It is not a dangerous sport if played properly. However, in the hands of children playing unsupervised, golf clubs are potentially lethal weapons. We recommend that children are supervised at all times when playing with golf clubs and that this should be done on a golf course.
1 Lindsay $\mathrm{KW}$, McClatchic G, Jennett B. Serious head injury in sport. B.Mf $1980 ; 281: 789-91$

2 Jennett B, Murray A. Head injuries in Scottish hospitals. Scottish head injury management study. Lancet 1977;ii:696-8.

3 Strang I, MacMillan R. Jennett B. Head injuries in accident and emergency departments at Scottish hospitals. Injury 1978;10:154-7.

4 Millar JD, Jennett WB. Complications of depressed skull fracture. Lancet 1968:ii:991-5.

(Accepted 7 7une 1991)

\title{
Intravenous drug misuse among prison inmates: implications for spread of HIV
}

\section{Stephen Dye, Chris Isaacs}

St Mary's Hospital Medical School, London W2 1PG Stephen Dve, medical student Chris Isaacs, medical student

Correspondence to: Mr S Dye, c/o Dr A J Pinching, Department of Immunologv, St Mary's Hospital Medical School, London W2 1 PG

B.MF 1991;302:1506
Although the Prison Reform Trust estimated in 1988 that 350-500 prisoners in England and Wales were infected with HIV,' only 63 were known to be positive for HIV antibody in 1989.' Some indication of intravenous drug misuse within British prisons has come from surveys of former prisoners while outside prison (K Dolan et al, unpublished data). ${ }^{3}$ No definitive research has been reported from within the British prison system. As Edinburgh has a high background rate of HIV infection among intravenous drug misusers we conducted a pilot survey of inmates in an Edinburgh prison to characterise intravenous drug misuse and risk of HIV infection within prison.

\section{Subjects, methods, and results}

The study was performed in Saughton Prison, Edinburgh, which houses about 500 male prisoners in different halls according to length of sentence; many inmates had been sentenced or were on remand for drug related offences. We carried out structured interviews consisting of personal questions and questions related to drug misuse and HIV infection after distribution to all inmates of a letter explaining the study; three halls were excluded because of time constraints. Volunteers informed their gallery officer if they wished to participate, but only we and the prisoner were present at interview.

Many drug users complained about their treatment in prison; others may not have volunteered because of worries over confidentiality, thus the sample may be unrepresentative of the prison population. Random selection was thought likely to introduce bias because of refusals. There were also obvious shortcomings in using self reported behaviour and HIV status. The study, therefore, in giving a glimpse of the behaviour of intravenous drug misusers in prison, identified the nature of the problem rather than gave a strict estimate of the prevalence of HIV or of risk behaviour.

In all, 123 inmates were interviewed $(32 \%$ of the available prison population), of whom 43 (35\%) admitted to having previously injected drugs. Twenty nine $(24 \%$ of the sample and $67 \%$ of the injectors) had injected drugs in prison. The table gives a breakdown of the responses. Drug injecting in prison was more common in short term and remand inmates than in long term prisoners. Forty nine $(40 \%)$ of the study group had been tested for HIV; of these, 15 had never injected drugs, and 13 reported themselves as being HIV positive. Four prisoners had shared needles but had never been tested. The prevalence of HIV infection was significantly higher among short term prisoners $\left(\chi^{2}=6 \cdot 72, \mathrm{p}<0 \cdot 01\right)$.

A total of 42 out of 43 intravenous drug misusers had injected outside prison, of whom $38(90 \%)$ had shared needles outside prison, 29 out of 43 had injected in prison, of whom $22(76 \%)$ had shared needles inside prison. Forty one inmates had shared needles at least once either inside or outside prison. Of the 13 inmates positive for HIV antibody, 12 had injected while in prison and 11 had shared needles in prison. This compares to the $30 \mathrm{HIV}$ negative or untested intravenous drug misusers, of whom 17 had injected and 11 had shared needles in prison. Of the 13 HIV positive inmates, six reported taking more oral drugs and injecting less both inside and outside prison than in the past, emphasising the changing pattern of drug misuse within the Lothian area. ${ }^{+}$

Data on intravenous drug misuse and HIV antibody status by category of prisoner

\begin{tabular}{lccccc}
\hline Category & $\begin{array}{c}\text { No of } \\
\text { inmates }\end{array}$ & $\begin{array}{c}\text { No } \\
\text { questioned }\end{array}$ & $\begin{array}{c}\text { No(\%) } \\
\text { intravenous } \\
\text { drug misusers }\end{array}$ & $\begin{array}{c}\text { No(\%) } \\
\text { injecting }\end{array}$ & $\begin{array}{c}\text { No } \\
\text { in prison for HIV }\end{array}$ \\
\hline Short term & 92 & 40 & $17(43)$ & $13(33)$ & 8 \\
Remand & 83 & 24 & $13(54)$ & $8(33)$ & 2 \\
Holding $\dagger$ & 78 & 22 & $5(23)$ & $4(18)$ & 2 \\
Long term $\ddagger$ & 64 & 14 & $2(14)$ & $2(14)$ & 1 \\
Served $>5$ years $\$$ & 62 & 23 & $6(26)$ & $2(9)$ & 0 \\
\hline Total & 379 & 123 & $43(35)$ & $29(24)$ & 13 \\
\hline
\end{tabular}

* Sentence of $<18$ months.

†Inmates at beginning of sentences of $>18$ months.

$\ddagger$ Sentence of $>18$ months.

$§$ Figures for one of two accommodation halls (plus one inmate from the other).

\section{Comment}

This study underlines the fact that intravenous drug misuse occurs to a worrying degree in prisons. We found that such behaviour is particularly a feature of short term and remand prisoners and that the prevalence of HIV infection was higher in short term inmates. This is probably because drug related offences mainly carry sentences of less than 18 months. Many remand prisoners were awaiting trial for similar offences. Furthermore, as more visits are allowed to remand prisoners there is a greater opportunity for obtaining drugs.

Although our study is unlikely to be representative of all prisons and may also comprise a somewhat skewed sample, it provides a valuable insight into the increasing problem of HIV and injecting drug misuse in prisons. To begin to tackle this problem further research on a much wider scale is required to document the extent of HIV risk activity within prisons and to determine optimal means of intervention to reduce the risk.

We thank all the prison staff at Saughton for their permission to conduct this study and their welcome. We also thank the inmates who volunteered and Dr A J Pinching for his help and advice. Financial help was provided by the Aids Virus Education Research Trust.

1 Prison Reform Trust. HIV, AIDS and prisons. London: Prison Reform Trust, 1988.

2 British Medical Association Foundation for AIDS. HIV and AIDS in prisons. London: BMA, 1989. (Parliamentary factsheet 7 .)

3 Carvell ALM, Hart GJ. Risk behaviours for HIV infection among drug users in prison. BMF 1990;300:1383-4.

4 Skidmore CA, Robertson JR, Robertson AA, Elton RA. After the epidemic follow up study of HIV seroprevalence and changing patterns of drug use. BMF 1990;300:219-23.

(Accepted 22 March 1991 